\title{
Physicochemical and textural quality attributes of gluten-free bread formulated with guar gum
}

\author{
Christian R. Encina-Zelada ${ }^{1,2,3}$ (1) $\cdot$ Vasco Cadavez $^{1} \cdot$ Fernando Monteiro $^{4,5} \cdot$ José A. Teixeira ${ }^{2} \cdot$ \\ Ursula Gonzales-Barron ${ }^{1}$
}

Received: 3 August 2018 / Revised: 24 September 2018 / Accepted: 29 September 2018 / Published online: 17 October 2018

c) Springer-Verlag GmbH Germany, part of Springer Nature 2018

\begin{abstract}
The objective of this study was to assess the combined effect of guar gum (GG) and water content (WC) on the rheological properties of batter, and the physicochemical and textural properties of bread. Batches of gluten-free bread used a base formulation of rice (50\%), maize (30\%) and quinoa flour (20\%), with different levels of GG $(2.5,3.0$ or 3.5\%) and water (90, 100 or $110 \%)$ in a full factorial design. Higher GG doses $(p<0.001)$ tended to produce batters of lower stickiness, work of adhesion and cohesive strength; yet, of higher firmness, consistency, cohesiveness and viscosity index. These batters yielded loaves of lower $(p<0.001)$ specific volume and baking loss; and crumbs of lower $(p<0.001) a_{\mathrm{w}}$, $\mathrm{pH}$, mean cell area, void fraction, mean cell aspect ratio; and higher $(p<0.001)$ hardness, adhesiveness, springiness, cohesiveness, chewiness, resilience, mean cell density, cell size uniformity and mean cell compactness. The sticker and less consistent batters produced with higher WC rendered larger bread loaves of softer and more cohesive and springy/resilient crumbs with greater mean cell size and void fraction. Gluten-free loaves of good appearance in terms of higher specific volume, lower crumb hardness, higher crumb springiness, and open grain visual texture were obtained in formulations with $110 \%$ WC and GG doses between 2.5 and $3.0 \%$.
\end{abstract}

Keywords Quinoa $\cdot$ Rice $\cdot$ Maize $\cdot$ Rheology $\cdot$ Texture profile analysis $\cdot$ Crumb image analysis

\section{Introduction}

The market of gluten-free (GF) bakery products has considerably grown; prompted not only by the people suffering coeliac disease and other gluten-related disorders; but also by a new segment of consumers who have chosen to consume GF foods as a lifestyle choice or for health reasons

Christian R. Encina-Zelada

cencina@lamolina.edu.pe

1 CIMO Mountain Research Centre, School of Agriculture, Polytechnic Institute of Bragança, Bragança, Portugal

2 Centre of Biological Engineering, School of Engineering, University of Minho, Braga, Portugal

3 Department of Food Technology, Faculty of Food Industries, National Agricultural University La Molina, Lima, Peru

4 Department of Electrical Engineering, School of Technology and Management, Polytechnic Institute of Bragança, Bragança, Portugal

5 INESC-TEC-Institute for Systems and Computer Engineering, Technology and Science, Porto, Portugal
[1]. Among the bakery products, bread is a major staple food consumed daily all over the world [1]. However, eliminating gluten seems a technological challenge as it gives rise to products with compromised quality [2]. To overcome this, a number of hydrocolloids have been studied as gluten replacers. Guar gum (GG) is a polysaccharide, obtained from Cyamopsis tetragonoloba beans. Its solutions are highly viscous at low concentrations and useful in thickening, stabilization and water binding applications [3]. In breadmaking, GG is used to improve mixing and recipe tolerance; to extend the shelf life of products through moisture retention and to improve quality of baked products such as volume, texture and colour (3-5). Optimising textural and sensory attributes, researchers have recommended doses of GG in GF bread, that, in general, range between $0.25 \%$ and $3.0 \%$ (flour weight), yet this is strongly linked to bread formulation and water content [3-5]. The protein network formed by GG has been found to be similar to the gluten structure, and when added to rice-wheat flour, it increases water absorption, dough development time, dough stability and viscosity $[6,7]$. 
Research interest in quinoa, a GF Andean grain, has been renewed due to its high nutritional and functional values. Apart from its good proximate composition profile, (protein $\sim 13.0 \%$, lipids $\sim 6.0 \%$ ), quinoa whole flour is rich in dietary fibre $(\sim 16.0 \%$, with ratios of insoluble dietary fibre/ soluble dietary fibre higher than 8:1), phenolic acids, flavonoids and $\alpha$-linolenic acid; suggesting that quinoa flour can be employed as an ingredient to enrich food systems [8, 9]. Rice flour, another commonly GF ingredient, is usually preferred because of its colourlessness, nutritional characteristics, mild taste, low hypoallergenic properties [10], low levels of sodium and easy digestibility [11]. Rice proteins have relatively poor functional properties, yet they can be enhanced in combination with quinoa proteins in breadmaking. Maize flour also contributes to GF breadmaking since their dietary fibre has been found to produce higher loaf volume and lower crumb hardness as compared to GF bread without coarse maize flour [2]. The objective of this study was to enhance the quality attributes of GF bread formulated with a mixture of quinoa, rice and maize flours by understanding the effect of guar gum, used as gluten replacer, on the rheological properties of batter and the physicochemical and textural properties of the baked loaves.

\section{Materials and methods}

\section{GF breadmaking process}

Quinoa flour was obtained from a commercial mixture of saponin-free white quinoa varieties: Salcedo INIA and Juli (grains mixture composition: $10.1 \%$ moisture, $13.6 \%$ protein, $3.2 \%$ crude fat, $3.1 \%$ ashes and $70 \%$ carbohydrates, particle size $\sim 1 \mathrm{~mm}$ ). Quinoa grains were milled in a laboratory disc mill (Faema, Spain), and then sieved through a rotating sifter. The quinoa flour had a particle size $<315 \mu \mathrm{m}$ measured using a test sieve (Retsch, Germany) and a vibratory sieve shaker (Retsch AS200 basic, Germany). Quinoa flour $(8.8 \%$ moisture, $12.9 \%$ protein, $5.0 \%$ fat, $2.2 \%$ ashes, and $71.1 \%$ carbohydrates) was kept in polyethylene containers and maintained at room temperature $\left(\sim 20^{\circ} \mathrm{C}\right)$ conditions during its use.

GF breads were elaborated with rice flour $(10.4 \%$ moisture, $7.6 \%$ protein, $0.7 \%$ fat and $78.5 \%$ carbohydrates, particle size $<180 \mu \mathrm{m})$, maize flour $(11.5 \%$ moisture, $5.4 \%$ protein, $2.1 \%$ fat and $78.3 \%$ carbohydrates, particle size $<180 \mu \mathrm{m}$ ), sunflower oil, white sugar and refined salt purchased from a local supermarket (Bragança, Portugal). Instant yeast (Saccharomyces cerevisiae lyophilized, Instaferm Lallemand, EU) and GG (E412) were provided by TecPan (Mirandela, Portugal). All batches were produced using a base formulation of rice flour (50\%), maize flour (30\%) and quinoa flour $(20 \%)$ to which sunflower oil (6\% flour weight), white sugar (3\% flour weight), refined salt (1.5\% flour weight), instant yeast (3\% flour weight), GG (2.5, 3.0 or $3.5 \%$ flour weight) and water (90, 100 or $110 \%$ flour weight) were added following a standardised procedure. Demineralised water $(\mathrm{pH}=6.8) \mathrm{kept}$ at $5{ }^{\circ} \mathrm{C}$ overnight was used. The instant yeast was rehydrated and activated at $30{ }^{\circ} \mathrm{C}$ and $85 \%$ of relative humidity (RH) for $15 \mathrm{~min}$ in a chamber. After mixing dry ingredients for $2 \mathrm{~min}$ at speed 1 , liquid ingredients were added and mixed for an additional $5 \mathrm{~min}$ at speed 4 in a professional food processor (SilverCrest SKMP-1200, Germany) equipped with a batter blade.

Portions of $\sim 280 \mathrm{~g}$ were then poured into oiled and floured $520-\mathrm{ml}$ capacity tins, and allowed to proof at $30^{\circ} \mathrm{C}$ and $85 \%$ of relative humidity for $60 \mathrm{~min}$ in a climatic chamber (Climacell 222, Germany). Afterwards, all moulds from the same batch were placed in a pre-heated convection oven (Princess, $2000 \mathrm{~W}$, The Netherlands) for $60 \mathrm{~min}$ at $190{ }^{\circ} \mathrm{C}$. Bread loaves were un-moulded after $2 \mathrm{~h}$. All analyses were performed after $24 \mathrm{~h}$. All batter and crumb rheology parameters were obtained using a texture analyser TA-XT plus implemented with the Exponent software version 6.1.11.0 (Stable Micro Systems, UK). For calibration, a 5-kg load cell for stickiness analysis, and a 30-kg load cell for backextrusion for the TPA analyses were used.

\section{Rheological properties of GF batter}

For analysis of the rheological properties of batter, $\sim 175 \mathrm{~g}$ was used. For the batter stickiness analysis, $\sim 5 \mathrm{~g}$ batter was weighed in a SMS/Chen-Hoseney stickiness cell (A/DSC) screwed to a SMS/Chen-Hoseney stickiness rig [12]; and then examined by the texture analyser using a $25-\mathrm{mm}$ perspex cylinder probe $(\mathrm{P} / 25 \mathrm{P})$, while parameters were set at: pre-test speed $0.5 \mathrm{~mm} / \mathrm{s}$, test speed $0.5 \mathrm{~mm} / \mathrm{s}$ and post-test speed $10 \mathrm{~mm} / \mathrm{s}$, trigger force $5 \mathrm{~g}$, applied force $40 \mathrm{~g}$, contact time $0.1 \mathrm{~s}$ and return $4 \mathrm{~mm}$. After rotating the cell screw once to extrude a 1-mm-high batter sample, the perspex cap was placed over the exposed sample surface to minimise moisture loss, whilst allowing the batter surface to rest for $30 \mathrm{~s}$ to release the stress produced by extrusion (Ghodke 2009). Ten repetitions were done for each GF batter formulation. Three stickiness analysis parameters were obtained: batter stickiness (STIba, in g), work of adhesion (ADHba, in $\mathrm{g} \cdot \mathrm{s}$ ), and batter cohesive strength (SCOba, in $\mathrm{mm}$ ) $[3,13]$.

The back-extrusion analysis was performed using a 35-mm-diameter perspex flat probe (model A/BE), a standard size back-extrusion cylindrical container $(50 \mathrm{~mm}$-diameter, capacity of $\sim 115 \mathrm{~g}$ ) and a backward extrusion rig (model $\mathrm{A} / \mathrm{BE})$. The container was filled with $\sim 85 \mathrm{~g}$ of batter $(75 \%$ full). The settings of the assessment were: pre-test speed $1 \mathrm{~mm} / \mathrm{s}$, test speed $2 \mathrm{~mm} / \mathrm{s}$ and post-test speed $2 \mathrm{~mm} / \mathrm{s}$, trigger force $10 \mathrm{~g}$, penetrated to a depth of $15 \mathrm{~mm}$ and then returned to starting position $[12,14]$. Four repetitions were 
tested from each batch of GF batter. Several back-extrusion parameters were obtained: firmness (FIRba, in g), consistency (CONba, in $\mathrm{g} \cdot \mathrm{s})$, cohesiveness (COHba, in g), and viscosity index (VISba, in g.s). Since COHba and VISba are calculated from the negative region of the back-extrusion profile curve, the higher the negative values, the more cohesive and viscous the batter, respectively.

\section{Physicochemical bread quality properties}

\section{Loaf-specific volume and baking loss}

The GF loaf volume (ml) was determined using a modified standard rapeseed displacement method 10-05 [15], using quinoa seeds instead of rapeseeds. The mould used to do the measurement was a parallelepiped with dimension of $10.4 \mathrm{~cm} \times 10.4 \mathrm{~cm} \times 7.5 \mathrm{~cm}$ (width $\times$ length $\times$ height). The loaf-specific volume $(\mathrm{ml} / \mathrm{g})$ was calculated as loaf volume divided by loaf weight measured $24 \mathrm{~h}$ after baking [16]. Baking loss was computed as [initial loaf weight before baking - the loaf weight after $24 \mathrm{~h}$ baking $\times 100]$ /initial loaf weight before baking $[17,18]$.

\section{Water activity, $\mathrm{pH}$ and colour}

Water activity $\left(a_{\mathrm{w}}\right)$ of the bread crumb was determined according to Machado-Alencar et al. [19], measured at $20{ }^{\circ} \mathrm{C}$ using an AquaLab (4TE Decagon, USA). Measurements were taken from four central slices from each loaf. Then, $\mathrm{pH}$ was measured according to Bhatt and Gupta [17]. Crust colour was measured on five different zones of the top of the entire loaf, while crumb colour was measured on the centre of five slices per each loaf using the $L^{*}, a^{*}$ and $b^{*}$ parameters according to colour space CIELab system, with a colorimeter CR-400 (Konica Minolta, chroma meter, Japan) which was calibrated using a white ceramic plate reference $\left(L^{*}=94.57, a^{*}=-0.46\right.$ and $\left.b^{*}=3.88\right)$ before each measurement. Additionally, the total colour difference $(\Delta E)$ of bread was determined as the following: $\Delta E=\left[\left(L_{0}-L\right)+\left(a_{0}-a\right)+\left(b_{0}-b\right)\right]^{0.5}$, where: $L_{0}=100$, $a_{0}=0$ and $b_{0}=0[20,21]$.

\section{Rheological properties of GF bread crumb}

The characterisation of the textural properties of bread crumb was carried out by means of the texture profile analysis (TPA). The GF loaves were sliced using an electric slicer (Bosch MAS4000W, Germany) to obtain 20-mm thickness. The two extreme slices of each loaf were discarded, and cylindrical crumb samples of $30 \mathrm{~mm}$-diameter were cut off from the centre of each slice. Four sub-samples were analysed per loaf. For the TPA, a 36-mm-diameter aluminium probe (model P/36R) was used. The analysis was run at: pre-test speed $1 \mathrm{~mm} / \mathrm{s}$, test speed $2 \mathrm{~mm} / \mathrm{s}$ and post-test speed $2 \mathrm{~mm} / \mathrm{s}$, trigger force $5 \mathrm{~g}, 50 \%$ sample deformation (strain) and double compression (with a gap of $30 \mathrm{~s}$ between the two cycles). The TPA parameters obtained were: hardness (HARbr, in g), adhesiveness (ADHbr, in $\mathrm{g} \cdot \mathrm{s}$ ), springiness (SPRbr, dimensionless), cohesiveness (COHbr, dimensionless), resilience (RESbr, dimensionless), and chewiness (CHEbr, in g) [22].

\section{Bread crumb image analysis}

Slices of bread were scanned (Canon Pixma MG-2550, Vietnam) using the IJ Scan Utility software (version 2.0.12, Canon, Japan) in grey level at $-10 \%$ brightness, $+15 \%$ contrast and 350 dpi resolution. Using the ImageJ software (v.1.51j8, Wayne Rasband, National Institute of Health, USA), the centre of the image was cropped into a $3.8 \mathrm{~cm} \times 3.8 \mathrm{~cm}$ field-of-view (with a spatial resolution of $1 \mathrm{~cm}=138$ pixels); and saved without any image compression in TIF format for posterior analysis. For each formulation, 32 images ( 4 loaves $\times 4$ slices $\times 2$ sides of the crumb) were acquired. Several grain crumb features were computed using the binary segmentation procedure based on the k-means clustering algorithm, proposed in Gonzales-Barron and Butler [23, 24], and were coded in Matlab software ver. R2015a [25]. These were: mean cell area $\left(\mathrm{MCA}, \mathrm{mm}^{2}\right.$ ); mean cell density $\left(\mathrm{CDE}\right.$, cells $\left./ \mathrm{mm}^{2}\right)$; cell size uniformity (UNI, dimensionless), calculated as the rate between the number of cells $\leq 5 \mathrm{~mm}^{2}$ and number of cells $>5 \mathrm{~mm}^{2}$; void fraction (VFR, dimensionless), calculated as the proportion of the two-dimensional space occupied by the cells; mean cell compactness (COM, dimensionless), with compactness defined as the ratio of the cell area of a circle having the same perimeter; and mean cell aspect ratio (ARA, dimensionless), with aspect ratio defined as the ratio of the major axis to the minor axis of a cell.

\section{Statistical analyses}

The effects of GG (three doses tested: $2.5,3.0$ or 3.5\%) and WC (three levels tested: 90,100 or $110 \%$ ) were evaluated using a full factorial design; thus, producing nine batches of GF bread. Analyses of variance were applied to assess the effect of GG, WC and their interaction on the response variables: baking loss, $\mathrm{pH}, a_{\mathrm{w}}$, batter stickiness and backextrusion. For the response variables: specific volume, crust and crumb $\triangle \mathrm{E}$, TPA and bread crumb image features, a linear mixed model was fitted instead to assess the main effects of GG dose and WC, and their interaction, assuming that measurements taken from the same loaf were correlated.

All two models were tested for the normality of residuals using standard diagnostics to ensure that all dependent variables met the assumptions of normal distribution. 
When the effects were significant ( $\alpha=0.05$ ), Tukey's Honest Significant Difference test was performed. Additionally, Kenward-Roger correction was applied for reducing small sample bias [26]. Statistical analyses were conducted using the packages "plyr", "ggplot2", "Ime4" and "ImerTest" for the linear models; and the packages: "rmisc", "rcmdmisc", "plyr", "ggplot2", "car", "multcompView" and "Ismeans" for the linear mixed models implemented in the R software version 3.3.3 [27].

\section{Results and discussion}

\section{Rheological properties of GF batter}

Both, GG and WC affected the rheology of GF batter, as implied by the results of the batter stickiness (Fig. 1) and the back-extrusion (Fig. 2) properties. The batter stickiness properties of STIba, ADHba and SCOba ranged from 33.56 to $45.33 \mathrm{~g}$, from 3.11 to $4.78 \mathrm{~g} \cdot \mathrm{s}$ and from 2.26 to $3.38 \mathrm{~mm}$, respectively. At a constant GG level, higher WC consistently $(p<0.001)$ increased the STIba, ADHba and
SCOba measurements, while at a constant WC level, higher GG contents consistently $(p<0.001)$ decreased the stickiness properties (Fig. 1). According to Table 1, GF batters with higher GG content were significantly less sticky, as demonstrated by the low values of STIba (36.1 g), ADHba $(3.80 \mathrm{~g} \cdot \mathrm{s})$ and SCOba $(2.74 \mathrm{~mm})$ for treatments with $3.5 \%$ GG, compared with $2.5 \% \mathrm{GG}(41.5 \mathrm{~g}, 4.64 \mathrm{~g} \cdot \mathrm{s}$ and $3.49 \mathrm{~mm}$, respectively) and 3.0\% GG (39.1 g, $4.15 \mathrm{~g} \cdot \mathrm{s}$ and $3.12 \mathrm{~mm}$, respectively). On the other hand, as expected, the treatments with the highest WC $(110 \% ; p<0.001)$ gave stickier batters $(41.7 \mathrm{~g}, 4.59 \mathrm{~g} \cdot \mathrm{s}$ and $3.19 \mathrm{~mm})$ than treatments with $90 \%$ WC (36.3 g, $3.74 \mathrm{~g} \cdot \mathrm{s}$ and $2.62 \mathrm{~mm}$, respectively) and 100\% WC ( $38.7 \mathrm{~g}, 4.26 \mathrm{~g} \cdot \mathrm{s}$ and $2.86 \mathrm{~mm}$, respectively). The flour's water absorption has an effect on batter stickiness for high water absorption reduces stickiness and produces stiff batters [28].

The treatments of GF bread studied produced batters of variable viscosity. The back extrusion analysis values ranged for FIRba from 757 to $2170 \mathrm{~g}$, for CONba from 4262 to $12,093 \mathrm{~g} \cdot \mathrm{s}$, for COHba from -580 to $-1645 \mathrm{~g}$, and for VISba from -1369 to $-4825 \mathrm{~g} \cdot \mathrm{s}$. Higher (3.5\%) GG contents increased $(p<0.001)$ FIRba $(1694 \mathrm{~g})$, CONba
Fig. 1 Effect of guar gum and water content on the gluten-free batter stickiness properties of STIba (top left), ADHba (top right) and SCOba (bottom)
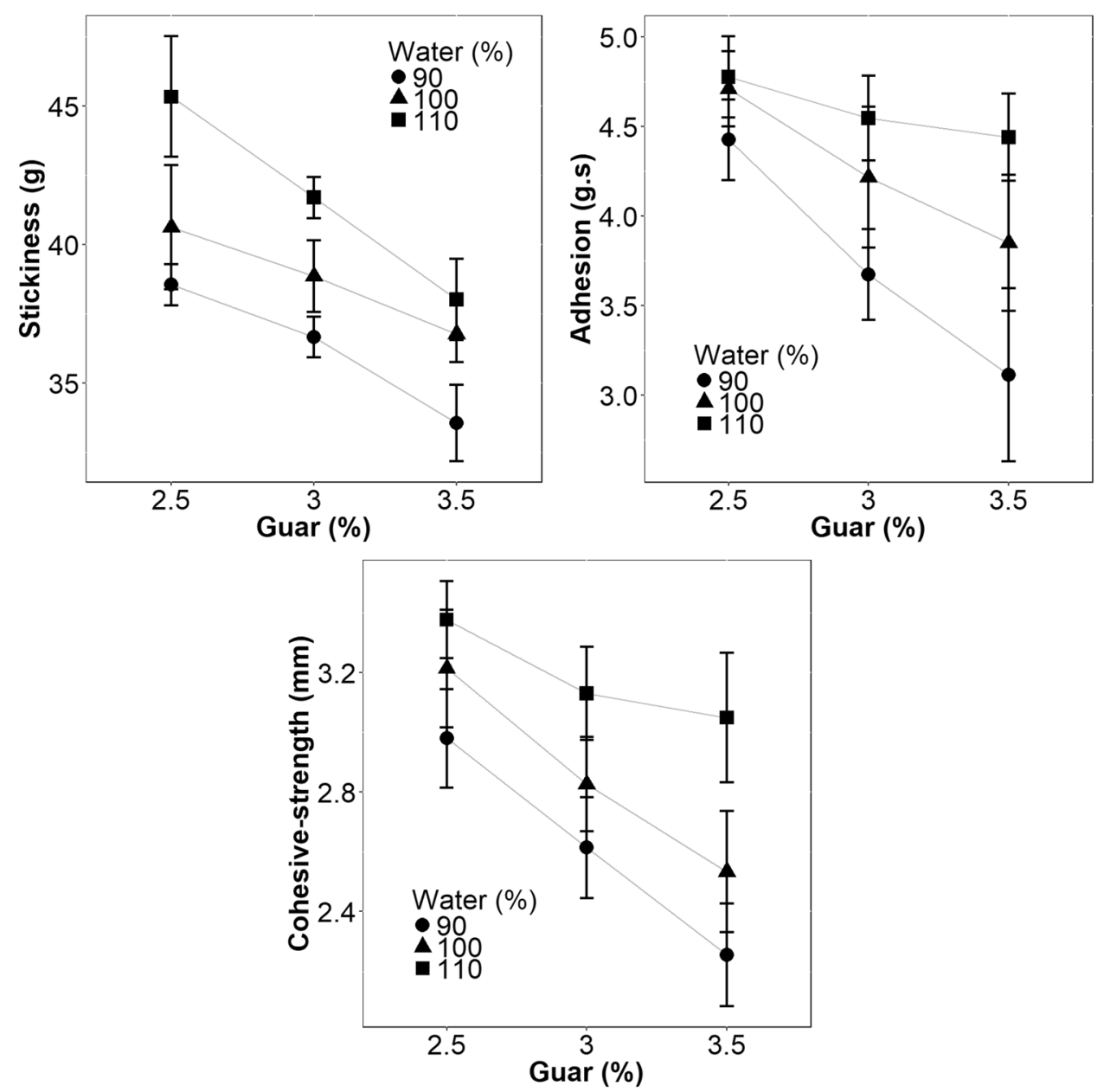
Fig. 2 Effect of guar gum and water content on the gluten-free batter back-extrusion properties of FIRba (top left), CONba (top right), $\mathrm{COHba}$ (bottom left) and VISba (bottom right)
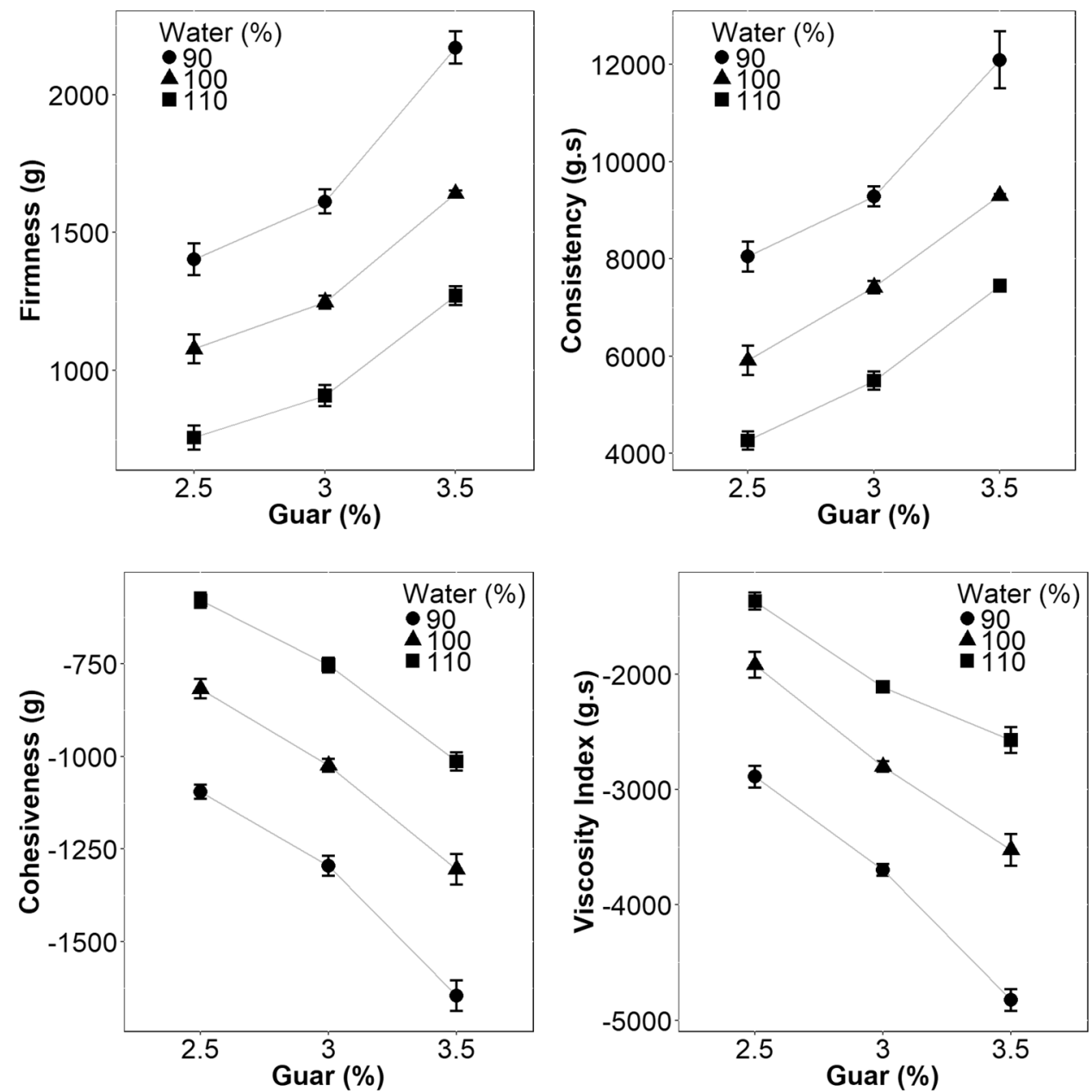

Table 1 Effect of guar gum and water content on the gluten-free batter properties of stickiness (STIba, g), work of adhesion (ADHba, g.s) and cohesive strength (SCOba, mm)

\begin{tabular}{|c|c|c|c|c|c|c|c|c|c|c|}
\hline \multirow[t]{2}{*}{ Effects } & \multirow[t]{2}{*}{$N^{*}$} & \multicolumn{3}{|c|}{ Stickiness (g) } & \multicolumn{3}{|c|}{ Work of adhesion $(\mathrm{g} \cdot \mathrm{s})$} & \multicolumn{3}{|c|}{ Cohesive strength (mm) } \\
\hline & & Mean & $95 \% \mathrm{CI}$ & $\operatorname{Pr}(>F)$ & Mean & $95 \% \mathrm{CI}$ & $\operatorname{Pr}(>F)$ & Mean & $95 \% \mathrm{CI}$ & $\operatorname{Pr}(>F)$ \\
\hline Guar (\%) & & & & $<0.001$ & & & $<0.001$ & & & $<0.001$ \\
\hline 2.5 & 10 & $41.5^{\mathrm{a}}$ & [41.0-42.0] & & $4.64^{\mathrm{a}}$ & {$[4.52-4.75]$} & & $3.49^{\mathrm{a}}$ & [3.43-3.54] & \\
\hline 3.0 & 10 & $39.1^{\mathrm{b}}$ & [38.6-39.6] & & $4.15^{\mathrm{b}}$ & {$[4.03-4.26]$} & & $3.12^{\mathrm{b}}$ & [3.06-3.17] & \\
\hline 3.5 & 10 & $36.1^{\mathrm{c}}$ & [35.6-36.6] & & $3.80^{\mathrm{c}}$ & {$[3.69-3.91]$} & & $2.74^{\mathrm{c}}$ & [2.68-2.80] & \\
\hline Water $(\%)$ & & & & $<0.001$ & & & $<0.001$ & & & $<0.001$ \\
\hline 90 & 10 & $36.3^{\mathrm{c}}$ & [35.7-36.7] & & $3.74^{\mathrm{c}}$ & {$[3.62-3.85]$} & & $2.62^{\mathrm{c}}$ & [2.55-2.68] & \\
\hline 100 & 10 & $38.7^{\mathrm{b}}$ & [38.3-39.2] & & $4.26^{\mathrm{b}}$ & {$[4.15-4.37]$} & & $2.86^{\mathrm{b}}$ & [2.80-2.92] & \\
\hline 110 & 10 & $41.7^{\mathrm{a}}$ & [41.1-42.2] & & $4.59^{\mathrm{a}}$ & {$[4.47-4.71]$} & & $3.19^{\mathrm{a}}$ & [3.12-3.25] & \\
\hline Interaction & & & & 0.006 & & & $<0.001$ & & & $<0.001$ \\
\hline
\end{tabular}

$N^{*}$ refers to the total number of batter portions for analysis

${ }^{\mathrm{a}, \mathrm{b}, \mathrm{c}}$ Different letters indicate significant differences $(p \leq 0.05)$

(9615 g·s), COHba (-1321 g) and VISba (-3640 g·s) of batters compared to results obtained from treatments with 2.5\% GG (1079 g, $6072 \mathrm{~g} \cdot \mathrm{s},-831 \mathrm{~g},-2060 \mathrm{~g} \cdot \mathrm{s}$, respectively) and 3.0\% GG (1256 g, $7398 \mathrm{~g} \cdot \mathrm{s},-1028 \mathrm{~g},-2871 \mathrm{~g} \cdot \mathrm{s}$, respectively) (Table 2). On the other hand, higher (110\%) water levels had an opposite effect, reducing $(p<0.001)$ FIRba (979 g), CONba (5735 g.s), COHba (-783 g) and VISba (-2018 g.s) of batters. Using the same level of water 


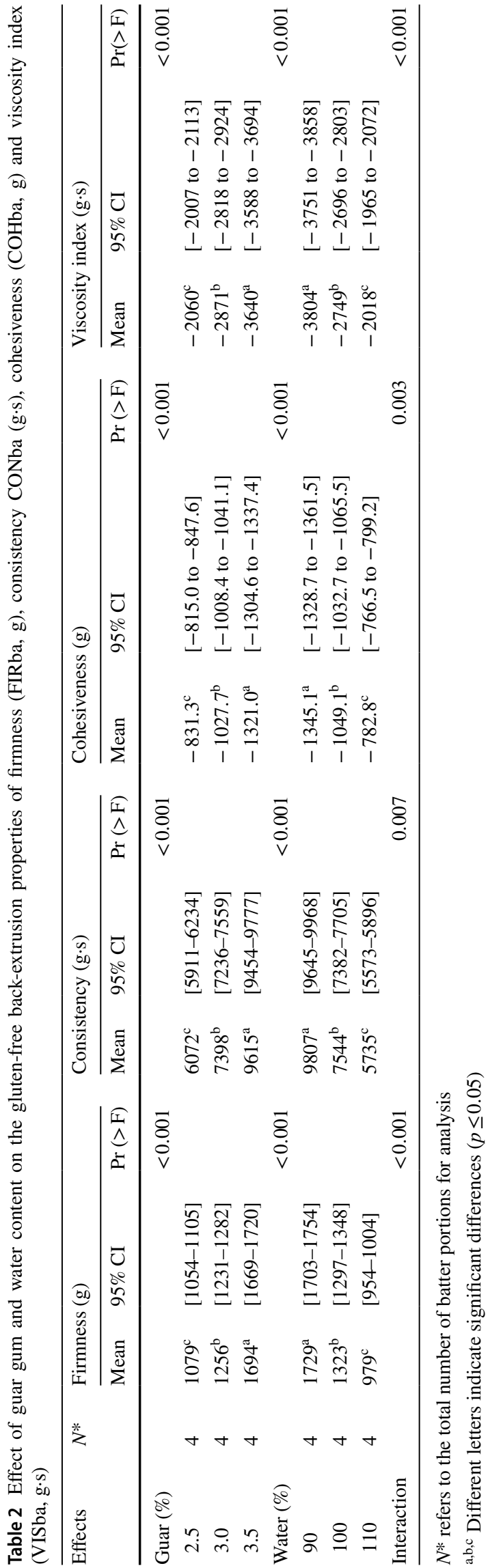

(110\%), Sciarini et al. [29] obtained lower batter firmness values, from 50.8 to $1252 \mathrm{~g}$, for a mixture of maize/soy (90:10) and rice/soy (80:20), respectively. They concluded that rice/soy mixtures required higher force to extrude, because soy proteins have the ability to absorb cold water, resulting in a decrease of free water in the batter mixture. In our case, quinoa proteins may have lent even a greater cold water absorption capability, hence producing batters of higher firmness than those with soy proteins.

All of the batter properties presented significant interaction between WC and GG (Tables 1,2), which can be also visualised in Figs. 1 and 2, whereby the effect of guar on batter rheology was more discernible at lower water contents. For instance, for the work of adhesion property, at a constant $\mathrm{WC}$ of $110 \%$, the change in GG from 2.5 to $3.5 \%$ increased ADHba by $\sim 7 \%$, while at the lowest WC of $90 \%$, the increase was higher at $\sim 42 \%$. Therefore, formulating bread with higher doses of GG may bring about greater and undesired variations in texture quality, if WC is not optimised. GG, consisting of galactose and mannose units, has the capacity to dissolve in polar solvents, forming strong hydrogen links; creating a highly viscous colloidal dispersion on complete hydration; such high viscosities may adversely affect the physico-chemical properties and sensory acceptability of foods [30]. Moreover, Funami et al. [31] and Horstmann et al. [32] explained the link between a high number of branches of GG and increased interactions with water. The higher the molecular weight (GG has between 100,000 and 2,000,000 Da), the greater the water holding capacity due to the higher radius of gyration (i.e., water around the hydrocolloid) [32].

Comparing between 1.5 and $2.5 \%$ of GG in a GF fresh filled pasta batter, Sanguinetti et al. [33] also observed that a higher dose of GG resulted in a more cohesive, springier and harder batter. Sabanis and Tzia [16] and Turkut et al. [18] reported that higher consistency values and viscosity index in their GF batters led to lower specific volume. This finding was corroborated in the present study, where $3.5 \% \mathrm{GG}$ doses produced loaves of lower specific volume $(1.5 \mathrm{ml} / \mathrm{g})$ compared to those obtained from treatments with $2.5 \% \mathrm{GG}$ $(1.8 \mathrm{ml} / \mathrm{g})$ (Fig. 3).

\section{Physicochemical properties of GF bread}

The specific volume, baking loss, $\mathrm{pH}$ and $a_{\mathrm{w}}$ values of GF breads are summarised in Table 3 , while side photographs of loaves produced varying GG and WC are displayed in Fig. 3 .

\section{Loaf-specific volume and baking loss}

Specific volume was affected $(p<0.001)$ by guar, hydration and their interaction (Table 3 ). The specific volume of bread ranged from 1.39 to $1.98 \mathrm{ml} / \mathrm{g}$, decreasing 
Fig. 3 Photographs of glutenfree bread loaves produced with varying guar gum $(\mathrm{GG})$ and water content (WC) showing length appearance. Scale bars $1 \mathrm{~cm}$

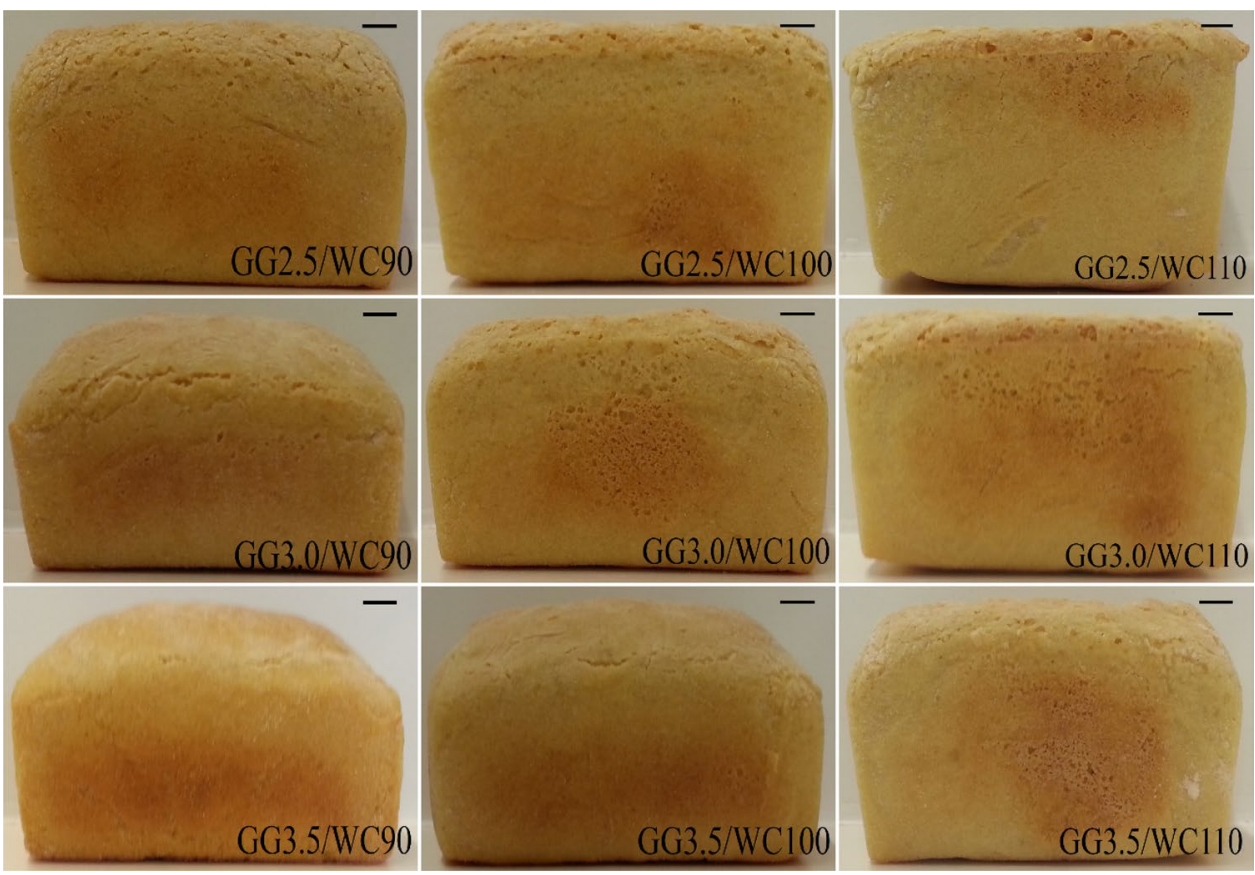

Table 3 Effect of guar gum and water content on the gluten-free bread physicochemical properties of specific volume (ml/g), baking loss (\%), $\mathrm{pH}, a_{\mathrm{w}}$ and total colour difference in crust and crumb

\begin{tabular}{|c|c|c|c|c|c|c|c|c|c|c|}
\hline \multirow[t]{2}{*}{ Effects } & \multirow[t]{2}{*}{$N^{*}$} & \multicolumn{3}{|c|}{ Specific volume (ml/g) } & \multicolumn{3}{|c|}{ Baking loss (\%) } & \multicolumn{3}{|l|}{$\mathrm{pH}$} \\
\hline & & Mean & $95 \% \mathrm{CI}$ & $\operatorname{Pr}(>F)$ & Mean & $95 \% \mathrm{CI}$ & $\operatorname{Pr}(>F)$ & Mean & $95 \% \mathrm{CI}$ & $\operatorname{Pr}(>F)$ \\
\hline Guar (\%) & & & & $<0.001$ & & & $<0.001$ & & & $<0.001$ \\
\hline 2.5 & 4 & $1.79^{\mathrm{a}}$ & {$[1.79-1.80]$} & & $16.43^{\mathrm{a}}$ & [16.30-16.55] & & $6.592^{\mathrm{a}}$ & [6.587-6.597] & \\
\hline 3.0 & 4 & $1.67^{\mathrm{b}}$ & [1.66-1.67] & & $14.90^{\mathrm{b}}$ & [14.77-15.02] & & $6.587^{\mathrm{b}}$ & {$[6.582-6.591]$} & \\
\hline 3.5 & 4 & $1.51^{\mathrm{c}}$ & {$[1.51-1.52]$} & & $13.54^{\mathrm{c}}$ & [13.41-13.66] & & $6.577^{\mathrm{c}}$ & {$[6.572-6.581]$} & \\
\hline Water $(\%)$ & & & & $<0.001$ & & & $<0.001$ & & & $<0.001$ \\
\hline 90 & 4 & $1.48^{\mathrm{c}}$ & {$[1.48-1.48]$} & & $13.71^{\mathrm{c}}$ & [13.59-13.84] & & $6.546^{\mathrm{c}}$ & {$[6.541-6.550]$} & \\
\hline 100 & 4 & $1.64^{\mathrm{b}}$ & [1.64-1.65] & & $14.97^{\mathrm{b}}$ & [14.84-15.09] & & $6.576^{\mathrm{b}}$ & {$[6.571-6.581]$} & \\
\hline 110 & 4 & $1.84^{\mathrm{a}}$ & [1.84-1.85] & & $16.18^{\mathrm{a}}$ & {$[16.06-16.31]$} & & $6.633^{\mathrm{a}}$ & [6.629-6.638] & \\
\hline Interaction & & & & $<0.001$ & & & $<0.001$ & & & 0.02 \\
\hline \multirow[t]{2}{*}{ Effects } & \multirow[t]{2}{*}{$N^{*}$} & \multicolumn{3}{|l|}{$a_{\mathrm{w}}$} & \multicolumn{3}{|c|}{ Crust $\Delta E$} & \multicolumn{3}{|c|}{ Crumb $\Delta E$} \\
\hline & & Mean & $95 \% \mathrm{CI}$ & $\operatorname{Pr}(>F)$ & Mean & $95 \% \mathrm{CI}$ & $\operatorname{Pr}(>F)$ & Mean & $95 \% \mathrm{CI}$ & $\operatorname{Pr}(>F)$ \\
\hline Guar (\%) & & & & $<0.001$ & & & $<0.001$ & & & 0.18 \\
\hline 2.5 & 4 & $0.9872^{\mathrm{a}}$ & [0.9870-0.9874] & & $41.8^{\mathrm{b}}$ & [41.3-42.2] & & $38.0^{\mathrm{a}}$ & [37.9-38.1] & \\
\hline 3.0 & 4 & $0.9838^{\mathrm{b}}$ & [0.9836-0.9841] & & $41.3^{\mathrm{b}}$ & [40.9-41.7] & & $38.1^{\mathrm{a}}$ & [38.0-38.3] & \\
\hline 3.5 & 4 & $0.9798^{c}$ & [0.9796-0.9801] & & $45.0^{\mathrm{a}}$ & [44.5-45.4] & & $38.1^{\mathrm{a}}$ & [38.0-38.3] & \\
\hline Water (\%) & & & & $<0.001$ & & & $<0.001$ & & & $<0.001$ \\
\hline 90 & 4 & $0.9808^{c}$ & [0.9806-0.9811] & & $41.2^{\mathrm{b}}$ & [40.7-41.6] & & $38.5^{\mathrm{a}}$ & [38.4-38.6] & \\
\hline 100 & 4 & $0.9834^{\mathrm{b}}$ & [0.9832-0.9837] & & $43.1^{\mathrm{a}}$ & [42.7-43.5] & & $37.8^{\mathrm{b}}$ & [37.7-37.9] & \\
\hline 110 & 4 & $0.9866^{\mathrm{a}}$ & [0.9864-0.9869] & & $43.8^{\mathrm{a}}$ & [43.4-44.2] & & $37.9^{\mathrm{b}}$ & [37.8-38.1] & \\
\hline Interaction & & & & $<0.001$ & & & 0.08 & & & 0.27 \\
\hline
\end{tabular}

$N^{*}$ refers to number of loaves

a,b,c Different letters indicate significant differences $(p \leq 0.05)$ 
$(p<0.001)$ with higher GG content, and increasing $(p<0.001)$ with higher WC. Specific volumes between 4 and $5 \mathrm{ml} / \mathrm{g}$ are usual for wheat breads depending on the formulation, breadmaking method and the use or not of sourdough; however, values between 1.33 and $2.40 \mathrm{ml} / \mathrm{g}$ are expected for GF bread [34, 35]. Similarly, Mohammadi et al. [6] working with 2.0-3.0\% GG obtained mean loafspecific volumes of 2.1 and $1.9 \mathrm{ml} / \mathrm{g}$, respectively, using a GF matrix of rice flour $(\sim 41 \%)$, maize starch $(\sim 31 \%)$, water $(59.5 \%$ and $62.7 \%$, respectively), soy flour $(\sim 10 \%)$, sodium caseinate $(\sim 5 \%)$, oil $(\sim 4 \%)$, sugar $(\sim 4 \%)$, inulin $(\sim 2 \%)$, salt $(\sim 1 \%)$, dried instant yeast $(\sim 1 \%)$ and DATEM $(\sim 0.2 \%)$, while Conte et al. [5] obtained a higher specific volume $(2.42 \mathrm{ml} / \mathrm{g})$ for a formulation of $1.5 \% \mathrm{GG}$ and $90 \% \mathrm{WC}$ in a matrix of GF rice flour $(50 \%)$, maize starch $(50 \%)$, psyllium fibre (1.5\%), sunflower oil $(6 \%)$, yeast $(3 \%)$, salt $(1.8 \%)$ and sugar $(3 \%)$.

According to Hager et al. [34], one important parameter in GF breadmaking, known to strongly influence consumer's choice, is loaf specific volume, because from an economic standpoint, a high ratio of volume per weight is desired. The positive impact of high WC was evident in the specific volume of GF breads, which can be explained by the plasticiser effect of water which contributes to the extensional properties of the batter during mixing, allowing the hydration of the particles [36]. Nonetheless, Han et al. [28] reported that excessive water can be detrimental as it causes overexpansion during baking resulting in collapsed loaves. Onyango et al. [37] explained that, as gas leaks out of the bubbles, it forces its way through the weakly connected particles and channels formed by gas pressing the particles apart. Since, in our experiments, small-sized bread loaves were mostly associated to lower baking losses, we can conclude that, regardless of the GG dose, batters with low WC tended to proof insufficiently, resulting in bread loaves of lower volume.

Baking loss ranged from 12.8 to $18.0 \%$, increasing $(p<0.001)$ with higher WC, and decreasing $(p<0.001)$ with higher GG content (Fig. 4). However, although higher GG amounts (3.5\%) reduce baking loss, it can negatively affect the volume of loaves (Fig. 4). Lower baking loss values $(13.5 \%)$ were obtained for $3.5 \%$ GG formulations, compared to those obtained from formulations with $2.5 \%$ GG (16.4\%) and 3.0\% GG (14.9\%) (Table 3). On the other hand, there was a proportional relationship between added water and baking loss; namely, 90, 100 and $110 \%$ of WC resulted in baking losses of 13.7, 15.0 and $16.2 \%$, respectively. As observed by Onyango et al. [37], formulations with high water contents gave mixtures that resembled batters, whereas those with low water amounts gave batters that lacked elasticity. Breads made from batters containing high water contents had higher volumes than those made from batters containing low water amount.
Water activity $\left(a_{\mathrm{w}}\right), \mathrm{pH}$ and colour

As expected, according to Table 3, the amount of free water in the crumb decreased with the addition of higher concentrations of GG $(p<0.001)$ and lower WC amounts $(p<0.001)$. The $a_{\mathrm{w}}$ ranged from 0.9777 to 0.9914 . Lower values of $a_{\mathrm{w}}(0.9798)$ were obtained for $3.5 \% \mathrm{GG}$, compared with $a_{\mathrm{w}}$ values obtained from treatments with $2.5 \%$ GG (0.9872) and 3.0\% GG (0.9838). On the other hand, 90, 100 and $110 \%$ of WC resulted in progressively increasing $\mathrm{a}_{\mathrm{w}}$ values of $0.9808,0.9834$ and 0.9866 , respectively. Since microbial stability of GF breads could be compromised by high $a_{\mathrm{w}}$, treatments with higher GG and lower WC amounts would be desired.

In relation to the $\mathrm{pH}$ parameter, bread acidity was also influenced by the addition of GG $(p<0.001)$ and WC $(p<0.001)$, with more acidic crumbs produced by higher doses of GG and lower doses of WC. GF breads showed a $\mathrm{pH}$ from 6.54 to 6.63. Lower $\mathrm{pH}$ values (6.58) were obtained for treatments with $3.5 \% \mathrm{GG}$, compared with $\mathrm{pH}$ values obtained from treatments with $2.5 \%$ GG (6.59) and $3.0 \%$ GG (6.59). On the other hand, $90 \% \mathrm{WC}(6.55)$ resulted in slightly less acidic crumbs, compared with $\mathrm{pH}$ values obtained from treatments with 100\% WC (6.58) and $110 \%$ WC (6.63).

All the GF bread crumb samples showed negative $a^{*}$ and positive $b^{*}$ values, indicating yellow-greenish hues, while bread crust samples showed positive $a^{*}$ and $b^{*}$ values, suggesting yellow-reddish hues. The colorimetric values of crust $\Delta E$ ranged from 39.6 to 45.7 , whereas for crumb $\Delta E$ ranged from 37.8 to 38.6 (Fig. 4). When proportions of WC $(p<0.001)$ increased, the crust $\Delta E$ increased. However, the GG showed a quadratic effect on crust $\Delta E$, while the crumb $\Delta E$ increased only by effect of lower amounts of WC $(p<0.001)$. Lee and Coates [38] and Motta-Romero et al. [21] stated that overall colour changes greater than $2(\Delta E>2)$ indicate a clear colour difference for consumers. For example, the formulation with 3.0\% GG and $90 \%$ WC compared to the $3.5 \% \mathrm{GG}$ and $90 \% \mathrm{WC}$ had a crumb $\Delta E(0.22)$ smaller than the crust $\Delta E(4.15)$. Therefore, consumers would be able to recognise the difference of colour between these two formulations only by appreciating the crust.

\section{Rheological properties of GF bread crumb}

All parameters of the TPA (HARbr, ADHbr, SPRbr, COHbr, CHEbr and RESbr) were affected $(p<0.001)$ by GG, WC (except for ADHbr, WC had no significant effect) and their interaction (Table 4). Having produced firmer and more viscous batters, lower WC levels consequently yielded tougher breads (Fig. 5). According to the TPA, loaves with the lowest WC (90\%) were significantly 
Fig. 4 Effect of guar gum and water content on the gluten-free bread physicochemical properties of specific volume (top left), baking loss (top right), $\mathrm{pH}$ (middle left), $a_{\mathrm{w}}$ (middle right), crust $\Delta E$ (bottom left) and crumb $\Delta E$ (bottom right) values
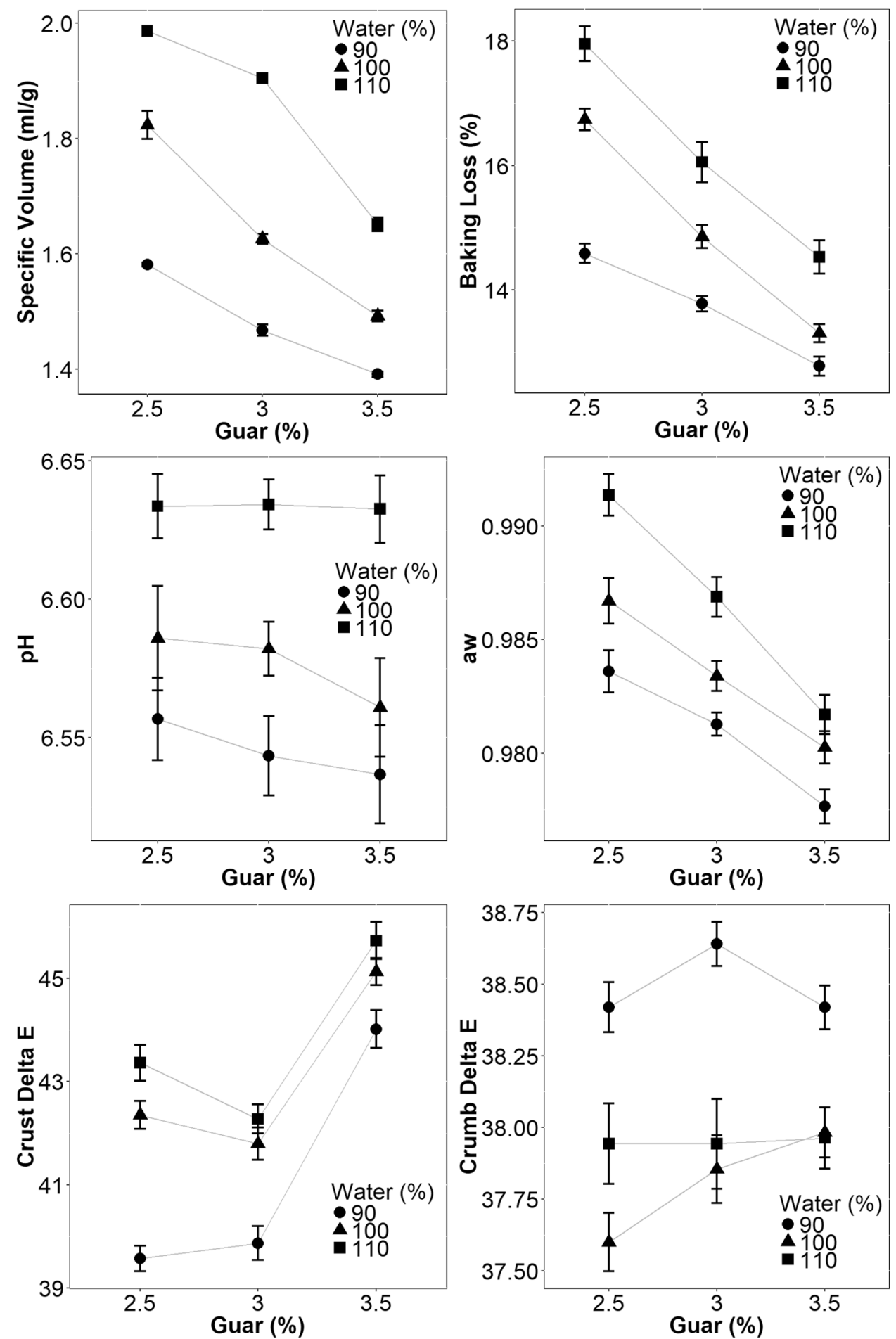

harder $($ HARbr $=8813 \mathrm{~g})$, chewier $(\mathrm{CHEbr}=3216 \mathrm{~g})$, and less cohesive $(\mathrm{COHbr}=0.472)$, springy $(\mathrm{SPRbr}=0.800)$ and resilient $(\mathrm{RESbr}=0.196)$ than the treatments with 100 and $110 \%$ WC. However, the addition of higher amounts of water can improve crumb texture, since the $110 \%$ WC treatments produced softer breads, with lower values of HARbr (2540 g) and CHEbr (1257 g), and higher values of SPRbr
(0.896), COHbr (0.552) and RESbr (0.241), compared to those obtained from the lower WC treatments of 90 and $100 \%$.

According to Cornejo and Rosell [11], high springiness values are preferred because it is related to the bread freshness and elasticity; a reduction in resilience or springiness characterises loss of elasticity, because both properties 
Table 4 Effect of guar gum and water content on the gluten-free bread instrumental textural profile analysis (TPA) properties of hardness (HARbr, g), adhesiveness (ADHbr, g.s), springiness (SPRbr, dimensionless), cohesiveness (COHbr, dimensionless), chewiness (CHEbr, g) and resilience (RESbr, dimensionless)

\begin{tabular}{|c|c|c|c|c|c|c|c|c|c|c|}
\hline \multirow[t]{2}{*}{ Effects } & \multirow[t]{2}{*}{$N^{*}$} & \multicolumn{3}{|c|}{ Hardness (g) } & \multicolumn{3}{|c|}{ Adhesiveness $(\mathrm{g} \cdot \mathrm{s})$} & \multicolumn{3}{|c|}{ Springiness } \\
\hline & & Mean & $95 \% \mathrm{CI}$ & $\operatorname{Pr}(>F)$ & Mean & $95 \% \mathrm{CI}$ & $\operatorname{Pr}(>F)$ & Mean & $95 \% \mathrm{CI}$ & $\operatorname{Pr}(>F)$ \\
\hline Guar (\%) & & & & $<0.001$ & & & $<0.001$ & & & $<0.001$ \\
\hline 2.5 & 2 & $4283^{c}$ & [4171-4396] & & $-9.49^{c}$ & {$[-4.5$ to -23.5$]$} & & $0.817^{\mathrm{b}}$ & [0.807-0.827] & \\
\hline 3.0 & 2 & $5244^{\mathrm{b}}$ & [5132-5357] & & $-43.63^{b}$ & {$[-29.6$ to -57.6$]$} & & $0.868^{\mathrm{a}}$ & {$[0.858-0.878]$} & \\
\hline 3.5 & 2 & $6757^{\mathrm{a}}$ & [6645-6870] & & $-90.51^{\mathrm{a}}$ & {$[-76.5$ to -104.5$]$} & & $0.865^{\mathrm{a}}$ & {$[0.855-0.875]$} & \\
\hline Water $(\%)$ & & & & $<0.001$ & & & 0.06 & & & $<0.001$ \\
\hline 90 & 2 & $8813^{\mathrm{a}}$ & [8700-8925] & & $-43.19^{\mathrm{a}}$ & {$[-29.2$ to -57.2$]$} & & $0.800^{\mathrm{c}}$ & {$[0.790-0.810]$} & \\
\hline 100 & 2 & $4932^{\mathrm{b}}$ & [4819-5044] & & $-42.36^{\mathrm{a}}$ & {$[-28.4$ to -56.3$]$} & & $0.854^{\mathrm{b}}$ & {$[0.845-0.864]$} & \\
\hline 110 & 2 & $2540^{c}$ & [2428-2653] & & $-58.08^{\mathrm{a}}$ & {$[-44.1$ to -72.1$]$} & & $0.896^{\mathrm{a}}$ & [0.886-0.906] & \\
\hline Interaction & & & & $<0.001$ & & & $<0.001$ & & & $<0.001$ \\
\hline \multirow[t]{2}{*}{ Effects } & $N^{*}$ & \multicolumn{3}{|c|}{ Cohesiveness } & \multicolumn{3}{|c|}{ Chewiness (g) } & \multicolumn{3}{|c|}{ Resilience } \\
\hline & & Mean & $95 \% \mathrm{CI}$ & $\operatorname{Pr}(>F)$ & Mean & $95 \% \mathrm{CI}$ & $\operatorname{Pr}(>F)$ & Mean & $95 \% \mathrm{CI}$ & $\operatorname{Pr}(>F)$ \\
\hline Guar (\%) & & & & $<0.001$ & & & $<0.001$ & & & $<0.001$ \\
\hline 2.5 & 2 & $0.433^{\mathrm{c}}$ & {$[0.427-0.440]$} & & $1318^{\mathrm{c}}$ & [1256-1381] & & $0.176^{\mathrm{c}}$ & {$[0.173-0.179]$} & \\
\hline 3.0 & 2 & $0.533^{\mathrm{b}}$ & [0.527-0.539] & & $2364^{\mathrm{b}}$ & [2302-2427] & & $0.224^{\mathrm{b}}$ & {$[0.221-0.227]$} & \\
\hline 3.5 & 2 & $0.555^{\mathrm{a}}$ & {$[0.548-0.561]$} & & $3216^{\mathrm{a}}$ & [3153-3279] & & $0.236^{\mathrm{a}}$ & {$[0.233-0.239]$} & \\
\hline Water (\%) & & & & $<0.001$ & & & $<0.001$ & & & $<0.001$ \\
\hline 90 & 2 & $0.472^{\mathrm{c}}$ & [0.466-0.479] & & $3474^{\mathrm{a}}$ & [3411-3537] & & $0.196^{\mathrm{b}}$ & [0.193-0.199] & \\
\hline 100 & 2 & $0.497^{\mathrm{b}}$ & [0.491-0.503] & & $2167^{b}$ & [2105-2230] & & $0.199^{b}$ & [0.196-0.202] & \\
\hline 110 & 2 & $0.552^{\mathrm{a}}$ & {$[0.545-0.558]$} & & $1257^{\mathrm{c}}$ & [1194-1320] & & $0.241^{\mathrm{a}}$ & {$[0.238-0.244]$} & \\
\hline Interaction & & & & $<0.001$ & & & $<0.001$ & & & $<0.001$ \\
\hline
\end{tabular}

$\mathrm{N}^{*}$ refers to number of loaves ${ }^{\mathrm{a}, \mathrm{b}, \mathrm{c}}$ different letters indicate significant differences $(p \leq 0.05)$

indicate the ability of a material to return to its original shape after stressing. In our work, the highest springiness was reached with a combination of $2.5 \% \mathrm{GG}$ and $110 \% \mathrm{WC}$; this is, the lowest dose of GG and the highest amount of water (Fig. 5). As reported by Onyango et al. [37], cohesiveness characterises the extent to which a material can be deformed before it ruptures, and reflects the internal cohesion of the material. Bread crumb with high cohesiveness is desirable because it forms a bolus, instead of disintegrating during mastication, whereas low cohesiveness indicates increased susceptibility of the bread to fracture or crumble. In this study, GF bread with amounts of 3.5\% GG and $110 \%$ WC attained the highest cohesiveness.

Cornejo and Rosell [11] achieved, for GF bread elaborated with different long grain rice flours, lower values for hardness (ranged from 361 to $1105 \mathrm{~g}$ ) and springiness (ranged from 0.68 to 0.80 ), and comparable values for resilience (from 0.20 to 0.35 ), chewiness (from 914 to $2066 \mathrm{~g}$ ) and cohesiveness (from 0.44 to 0.67). Likewise, Onyango et al. [37] obtained, for GF bread elaborated with different rice, cassava, potato and maize starches-sorghum ratios, comparable TPA values for firmness (i.e., hardness) from 760 to $4862 \mathrm{~g}$ and chewiness (from 666 to $2383 \mathrm{~g}$ ), although they measured higher values for cohesiveness (from 0.563 to 0.756 ), springiness (from 0.875 to 0.997 ) and resilience (from 0.328 to 0.438 ). Conte et al. [5] obtained lower HARbr (3.79 N, i.e., $386 \mathrm{~g}$ ), and higher COHbr (0.60), SPRbr (0.99) and RESbr (0.31) for a formulation of $1.5 \% \mathrm{GG}$ and $90 \%$ WC in a matrix of GF rice flour (50\%), maize starch (50\%), psyllium fibre (1.5\%), sunflower oil (6\%), yeast (3\%), salt $(1.8 \%)$ and sugar $(3 \%)$.

\section{Image analysis features of crumb grain}

Digital images of GF crumb grain showed visual differences among the nine formulations (Fig. 6). Whereas higher WC formulations produced more open grain textures, lower WC formulations produced the opposite, closer crumbs of smaller pores. Such differences were statistically corroborated in all of the image grain features analysed. Values were in the range of $0.60-2.21 \mathrm{~mm}^{2}$ for MCA; $0.18-0.36$ cells/ $\mathrm{mm}^{2}$ for CDE; 8.46-157.3 for UNI; 0.189-0.358 for VFR; 0.767-0.803 for COM; and 1.526-1.703 for ARA.

Higher doses of GG produced loaf slices of lower MCA, VFR and ARA values $(p<0.001)$, and higher CDE, UNI and COM $(p<0.001)$. At a constant level of water in the 
Fig. 5 Effect of guar gum and water content on the gluten-free bread instrumental textural profile analysis (TPA) properties of HARbr (top left), ADHbr (top right), SPRbr (middle left), COHbr (middle right), $\mathrm{CHEbr}$ (bottom left) and RESbr (bottom right)
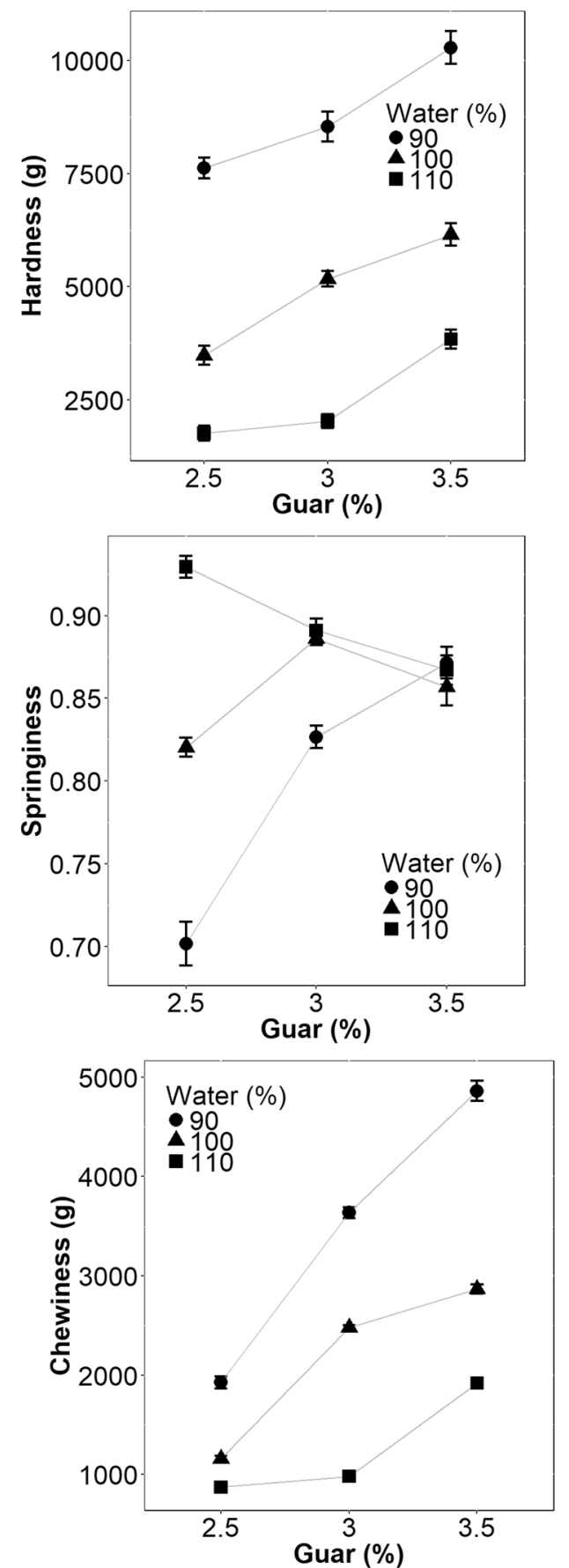
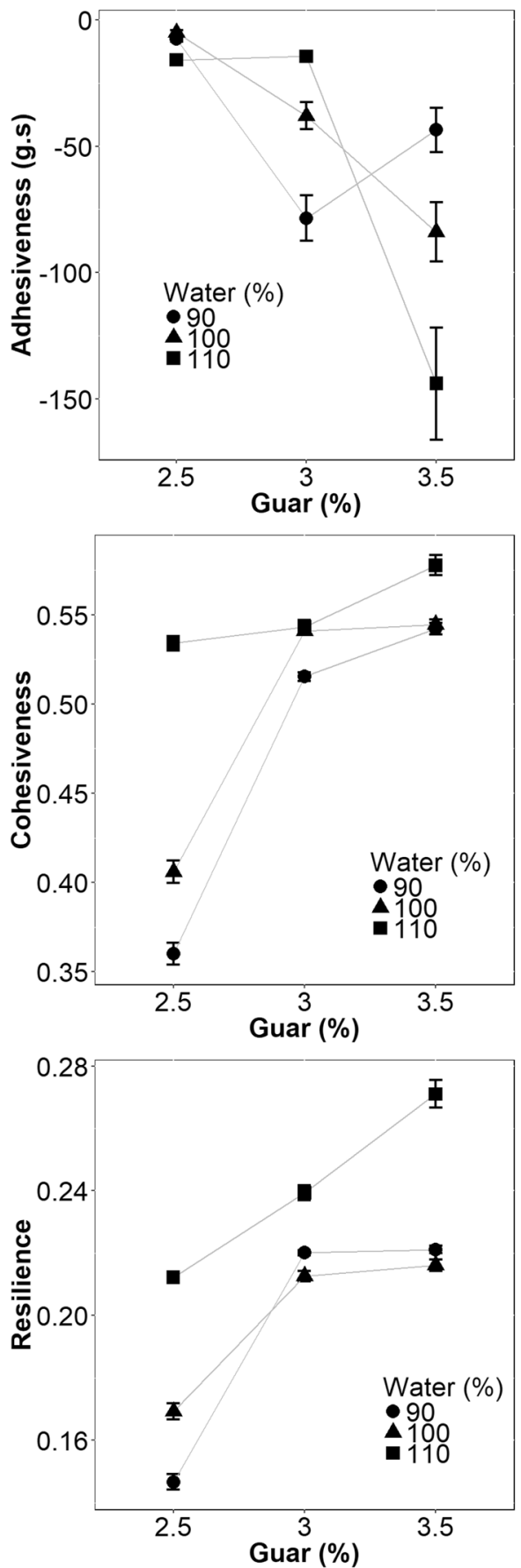

formulation, increasing GG doses only produces smaller bread loaves. These smaller loaves tend to have a compact or close visual grain texture, formed of a greater number of cells, but of smaller size. As a consequence, the cell size uniformity is greater but the void fraction is lower. Smaller loaves of denser or more compact texture also present the characteristic of having more rounded cells (i.e., higher cell compactness) and less elongated cells (i.e., lower mean cell aspect ratio). Loaves of lower GG contents (2.5\%) presented crumbs of larger pores, with higher values of MCA
(1.55 $\left.\mathrm{mm}^{2}\right)$, VFR (0.31) and ARA (1.67), and therefore lower values of CDE $\left(0.24\right.$ cells $\left./ \mathrm{mm}^{2}\right)$, UNI (19.7) and COM (0.77) compared to those obtained with higher GG levels of 3.0 and $3.5 \%$ (Table 5; Fig. 7).

On the other hand, when higher proportions of WC $(110 \%)$ were added, the opposite was observed; that is, values of CDE $\left(0.23\right.$ cells $\left./ \mathrm{mm}^{2}\right)$, UNI (15.4) and COM (0.770) were lower $(p<0.001)$, while values of MCA $\left(1.67 \mathrm{~mm}^{2}\right)$, VFR (0.32) and ARA (1.67) were higher than those obtained with the lower WC treatments of 90 and $100 \%$. This signifies 
Fig. 6 Crumb grain of glutenfree bread produced by varying guar gum (GG) and water content (WC). Scale bars $1 \mathrm{~cm}$

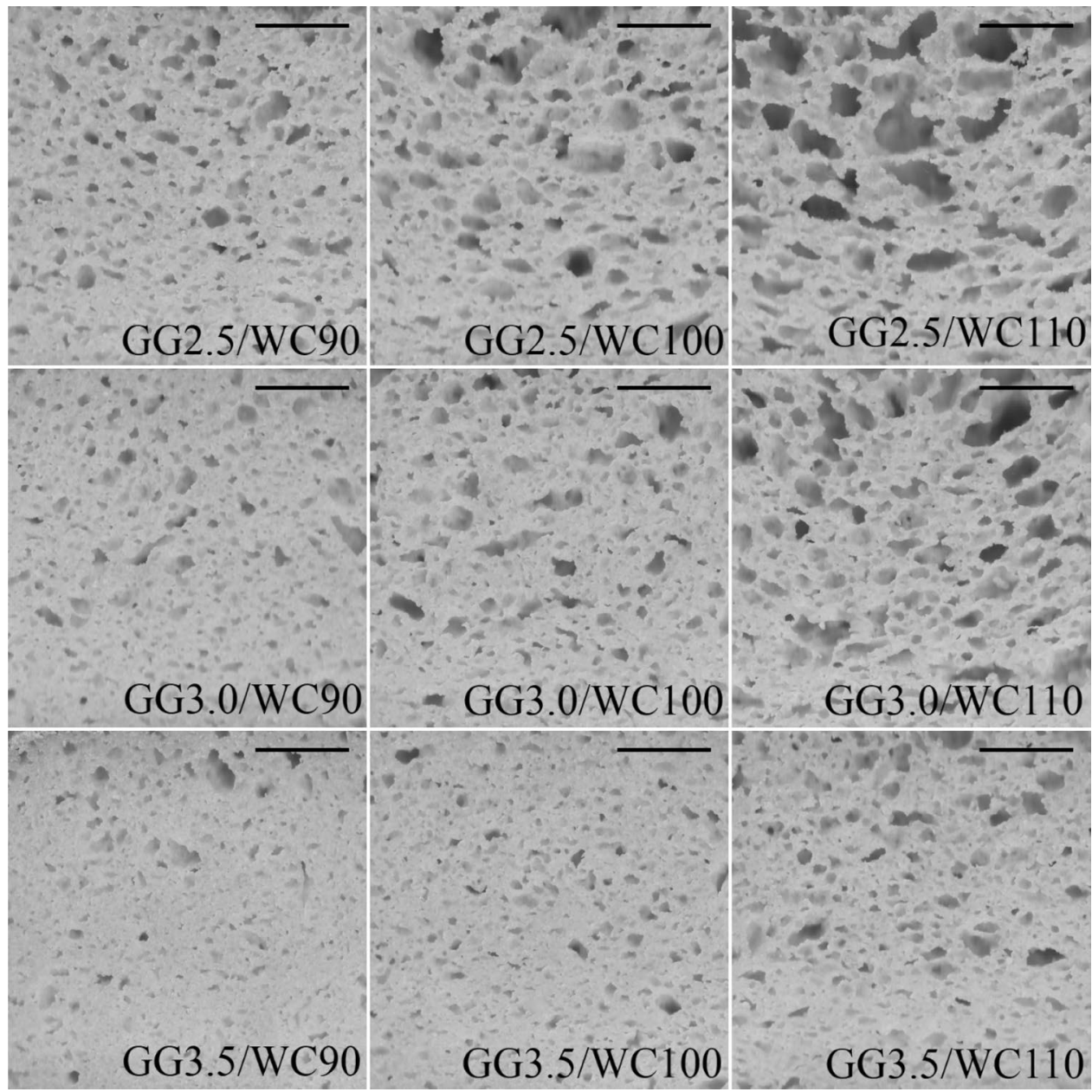

that, when loaves undergo a better proofing, expanding more during fermentation and baking, facilitated by the greater amount of water, the final visual texture of the bread crumb has altogether a different crumb grain. As breads are formulated with a constant GG dose and increasing WC levels, crumb grains tend to appear more open; in other words, the crumb is made of cells of greater size and less compact and more elongated shape. This in turn leads to a less uniform grain (since the number of large cells is greater) and a higher void fraction.

A denser bread crumb grain can also be effectively evaluated by the measurements of cell size uniformity and mean cell compactness or mean cell aspect ratio. Notice that higher values of UNI and COM were obtained with higher amounts of GG (3.5\%) and lower values of WC (90\%), corresponding in both cases to a denser crumb structure (Fig. 7). Thus, when during proofing and baking, batter expands more and steadily, a greater number of large cells is produced, therefore bringing down the ratio small-to-large cells (UNI), while due to coalescence, the large cells tend to be more elongated and less compact, thereby bringing down the values of COM.
From the nine formulations, the more open crumb grain was attained by the formulation with $2.5 \%$ GG and $110 \%$ WC (MCA value of $2.21 \mathrm{~mm}^{2}$; Fig. 7), whereas the formulation with $3.5 \%$ GG and 90\% WC produced the smallest mean cell size $\left(0.60 \mathrm{~mm}^{2}\right)$, characterising the denser structure obtained, which was also reflected by the lowest specific volume of this formulation $(1.39 \mathrm{ml} / \mathrm{g}$; Fig. 3). According to de la Hera et al. [36], if GF breads are elaborated with excessive water, large holes can appear in the crumb, as was also attested in our experiments for the formulation GG2.5/ WC110 (Fig. 7).

In this study, using GG as the only batter thickener, it was possible to obtain crumbs with open grain structures at a high level of water (110\%) and a low level of GG (2.5\%). The presence of larger cells can also be linked to a spongier crumb structure, which is a desirable quality property yet not typically found in gluten-free breads. Similar to our findings were those reported by Schober, Messerschmidt, Bean, Park, \& Arendt [39], who encountered that sorghum bread with a fine crumb structure was tougher than bread with a coarse and open crumb structure. In this study, it was possible to obtain crumbs of open grain in bread loaves formulated with 
Table 5 Effect of guar gum and water content on the gluten-free bread crumb grain features of mean cell area $\left(\mathrm{MCA}, \mathrm{mm}^{2}\right)$, mean cell density (CDE, cells $/ \mathrm{mm}^{2}$ ), cell size uniformity (UNI, dimensionless),

\begin{tabular}{|c|c|c|c|c|c|c|c|c|c|c|}
\hline \multirow[t]{2}{*}{ Effects } & \multirow[t]{2}{*}{$N^{*}$} & \multicolumn{3}{|c|}{ Mean cell area $\left(\mathrm{mm}^{2}\right)$} & \multicolumn{3}{|c|}{ Mean cell density (cells/mm²) } & \multicolumn{3}{|c|}{ Uniformity } \\
\hline & & Mean & $95 \% \mathrm{CI}$ & $\operatorname{Pr}(>F)$ & Mean & $95 \% \mathrm{CI}$ & $\operatorname{Pr}(>F)$ & Mean & $95 \% \mathrm{CI}$ & $\operatorname{Pr}(>F)$ \\
\hline Guar (\%) & & & & $<0.001$ & & & $<0.001$ & & & $<0.001$ \\
\hline 2.5 & 8 & $1.55^{\mathrm{a}}$ & {$[1.52-1.59]$} & & $0.240^{\mathrm{c}}$ & {$[0.235-0.245]$} & & $19.7^{\mathrm{c}}$ & {$[6.5-32.8]$} & \\
\hline 3.0 & 8 & $1.17^{\mathrm{b}}$ & {$[1.13-1.21]$} & & $0.286^{\mathrm{b}}$ & {$[0.281-0.290]$} & & $50.9^{\mathrm{b}}$ & {$[37.8-64.1]$} & \\
\hline 3.5 & 8 & $0.79^{\mathrm{c}}$ & {$[0.75-0.83]$} & & $0.327^{\mathrm{a}}$ & {$[0.322-0.332]$} & & $87.2^{\mathrm{a}}$ & [74.0-100.3] & \\
\hline Water $(\%)$ & & & & $<0.001$ & & & $<0.001$ & & & $<0.001$ \\
\hline 90 & 8 & $0.74^{\mathrm{c}}$ & {$[0.71-0.78]$} & & $0.336^{\mathrm{a}}$ & {$[0.322-0.341]$} & & $103.1^{\mathrm{a}}$ & [90.0-116.2] & \\
\hline 100 & 8 & $1.10^{\mathrm{b}}$ & [1.06-1.14] & & $0.287^{\mathrm{b}}$ & {$[0.282-0.292]$} & & $39.3^{\mathrm{b}}$ & {$[28.1-52.4]$} & \\
\hline 110 & 8 & $1.67^{\mathrm{a}}$ & {$[1.63-1.71]$} & & $0.229^{c}$ & {$[0.225-0.234]$} & & $15.4^{\mathrm{c}}$ & {$[2.3-27.6]$} & \\
\hline Interaction & & & & $<0.001$ & & & $<0.001$ & & & 0.001 \\
\hline \multirow[t]{2}{*}{ Effects } & $N^{*}$ & \multicolumn{3}{|c|}{ Void fraction } & \multicolumn{3}{|c|}{ Mean cell compactness } & \multicolumn{3}{|c|}{ Mean cell aspect ratio } \\
\hline & & Mean & $95 \% \mathrm{CI}$ & $\operatorname{Pr}(>F)$ & Mean & $95 \% \mathrm{CI}$ & $\operatorname{Pr}(>F)$ & Mean & $95 \% \mathrm{CI}$ & $\operatorname{Pr}(>F)$ \\
\hline Guar (\%) & & & & $<0.001$ & & & $<0.001$ & & & $<0.001$ \\
\hline 2.5 & 8 & $0.310^{\mathrm{a}}$ & {$[0.307-0.314]$} & & $0.770^{\mathrm{c}}$ & {$[0.768-0.772]$} & & $1.667^{\mathrm{a}}$ & [1.661-1.682] & \\
\hline 3.0 & 8 & $0.275^{\mathrm{b}}$ & {$[0.272-0.278]$} & & $0.783^{\mathrm{b}}$ & {$[0.781-0.784]$} & & $1.621^{\mathrm{b}}$ & [1.612-1.631] & \\
\hline 3.5 & 8 & $0.228^{c}$ & {$[0.225-0.232]$} & & $0.793^{\mathrm{a}}$ & {$[0.792-0.795]$} & & $1.571^{\mathrm{c}}$ & [1.561-1.582] & \\
\hline Water (\%) & & & & $<0.001$ & & & $<0.001$ & & & $<0.001$ \\
\hline 90 & 8 & $0.221^{\mathrm{c}}$ & {$[0.218-0.224]$} & & $0.796^{\mathrm{a}}$ & [0.794-0.797] & & $1.559^{\mathrm{c}}$ & [1.551-1.570] & \\
\hline 100 & 8 & $0.272^{\mathrm{b}}$ & {$[0.269-0.275]$} & & $0.781^{b}$ & [0.779-0.782] & & $1.626^{\mathrm{b}}$ & [1.621-1.631] & \\
\hline 110 & 8 & $0.321^{\mathrm{a}}$ & {$[0.318-0.324]$} & & $0.770^{\mathrm{b}}$ & {$[0.768-0.771]$} & & $1.674^{\mathrm{a}}$ & [1.672-1.681] & \\
\hline Interaction & & & & $<0.001$ & & & $<0.001$ & & & $<0.001$ \\
\hline
\end{tabular}

$N^{*}$ refers to the images acquired from four slices per each loaf

a,b,c Different letters indicate significant differences $(p \leq 0.05)$

high levels of water and low levels of GG. It is important to indicate that, in this study, the GG dose and water content were not statistically optimised, yet, with the experimental design used, a good understanding of their combined effects of the rheological and textural properties of the GF bread was achieved. Further studies can be conducted to optimise the formulation. In addition, it is desirable to elucidate the effects of other hydrocolloids such as hydroxypropyl methylcellulose or carboxymethylcellulose, and their synergistic behaviour with GG in quinoa-based GF bread. void fraction (VFR, dimensionless), mean cell compactness (COM, dimensionless), and mean cell aspect ratio (ARA, dimensionless) 
Fig. 7 Effect of guar gum and water content on the glutenfree bread crumb grain features of MCA (top left), CDE (top right), UNI (middle left), VFR (middle right), COM (bottom left) and ARA (bottom right)
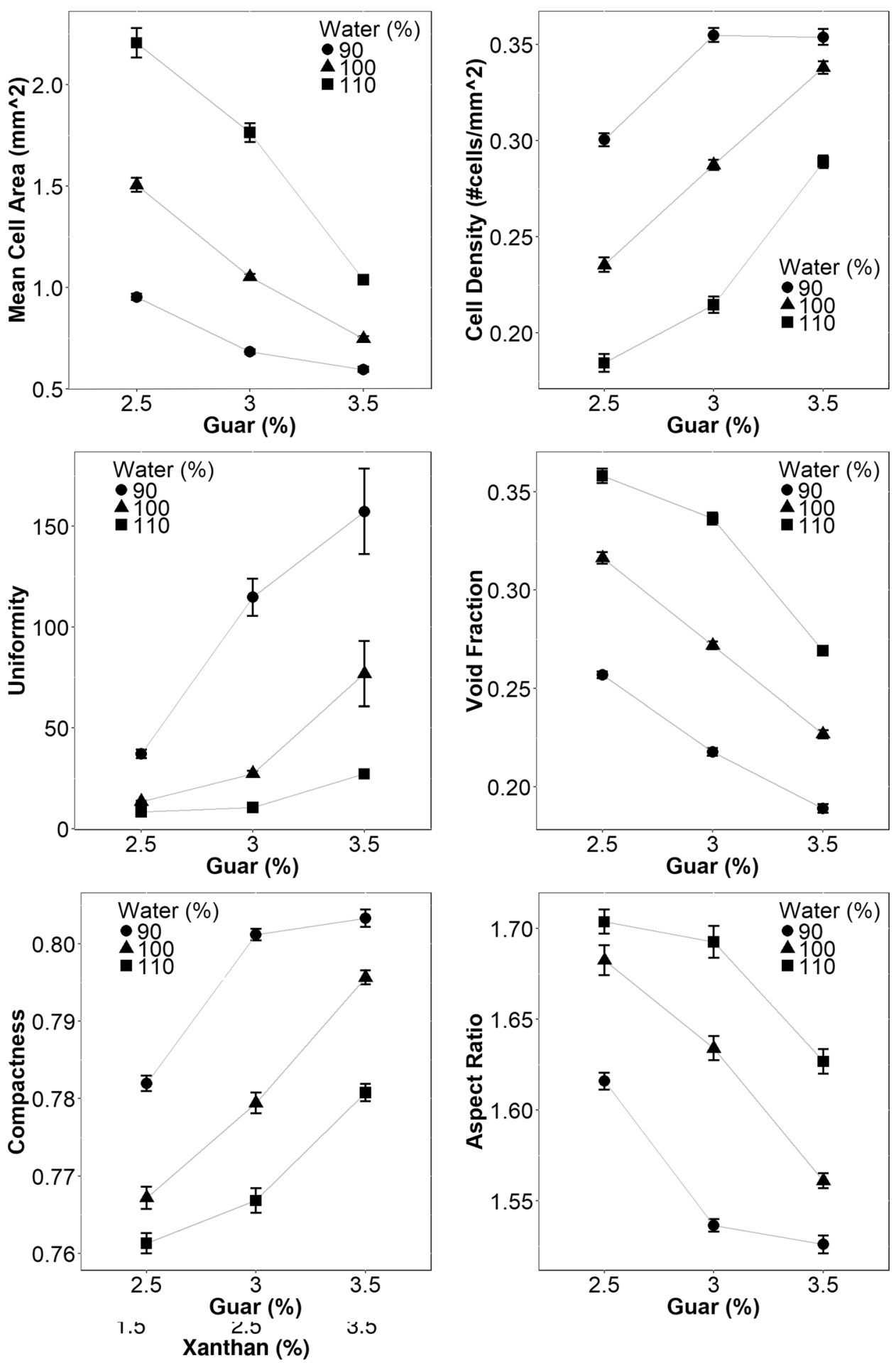
Acknowledgements Eng. Encina-Zelada acknowledges the financial aid provided by the Peruvian National Programme of Scholarships and Student Loans (PRONABEC) in the mode of PhD grants (Presidente de la República-183308). The authors are grateful to Eng. Andrea Oliveira from Prodipani, Portugal, for her kind advice and providing breadmaking ingredients.

\section{Compliance with ethical standards}

Conflict of interest The authors declare that they have no conflict of interest.

Research involving human participants and/or animals This article does not contain any studies with human or animal subjects.

\section{References}

1. Foschia M, Horstmann S, Arendt EK, Zannini E (2016) Nutritional therapy-facing the gap between coeliac disease and gluten-free food. Int J Food Microbiol 239:113-124

2. Naqash F, Gani A, Gani A, Masoodi FA (2017) Gluten-free baking: combating the challenges - a review. Trends Food Sci Technol 66:98-107

3. Ghodke SK (2009) Effect of guar gum on dough stickiness and staling in chapatti-an Indian unleavened flat bread. Int J Food Eng 5(3):article 7

4. Moreira R, Chenlo F, Torres MD (2013) Effect of chia (Sativa hispanica L.) and hydrocolloids on the rheology of glutenfree doughs based on chestnut flour. LWT-Food Sci Technol 50(1):160-166

5. Conte P, Del Caro A, Balestra F, Piga A, Fadda C (2018) Bee pollen as a functional ingredient in gluten-free bread: a physical-chemical, technological and sensory approach. LWT-Food Sci Technol 90:1-7

6. Mohammadi M, Azizi M-H, Neyestani TR, Hosseini H, Mortazavian AM (2015) Development of gluten-free bread using guar gum and transglutaminase. J Ind Eng Chem 21:1398-1402

7. Sahraiyan B, Naghipour F, Karimi M, Davoodi MG (2013) Evaluation of Lepidium sativum seed and guar gum to improve dough rheology and quality parameters in composite rice-wheat bread. Food Hydrocoll 30(2):698-703

8. Pellegrini M, Lucas-Gonzales R, Ricci A, Fontecha J, Fernández-López J, Pérez-Álvarez JA, Viuda-Martos M (2018) Chemical, fatty acid, polyphenolic profile, techno-functional and antioxidant properties of flours obtained from quinoa (Chenopodium quinoa Willd) seeds. Ind Crops Prod 111:38-46

9. Elgeti D, Nordlohne SD, Föste M, Besl M, Linden MH, Heinz V, Jekle M, Becker T (2014) Volume and texture improvement of gluten-free bread using quinoa white flour. J Cereal Sci 59(1):41-47

10. Renzetti S, Rosell CM (2016) Role of enzymes in improving the functionality of proteins in non-wheat dough systems. J Cereal Sci 67:35-45

11. Cornejo F, Rosell CM (2015) Physicochemical properties of long rice grain varieties in relation to gluten free bread quality. LWT-Food Sci Technol 62(2):1203-1210

12. Devi PB, Kavitake D, Shetty PH (2016) Physico-chemical characterization of galactan exopolysaccharide produced by Weissella confusa KR780676. Int J Biol Macromol 93:822-828

13. Agrahar-Murugkar D, Gulati P, Kotwaliwale N, Gupta C (2015) Evaluation of nutritional, textural and particle size characteristics of dough and biscuits made from composite flours containing sprouted and malted ingredients. J Food Sci Tech 52(8):5129-5137

14. Juszczak L, Witczak T, Ziobro R, Korus J, Cieślik E, Witczak M (2012) Effect of inulin on rheological and thermal properties of gluten-free dough. Carbohydr Polym 90(1):353-360

15. AACC International (2000) Method 10-05, approved methods of the AACC, 10th edn. American Association of cereal chemists, St. Paul

16. Sabanis D, Tzia C (2010) Effect of hydrocolloids on selected properties of gluten-free dough and bread. Food Sci Technol Int 17(4):279-291

17. Bhatt SM, Gupta RK (2015) Bread (composite flour) formulation and study of its nutritive, phytochemical and functional properties. J Pharmacogn Phytochem 4(2):254-268

18. Turkut GM, Cakmak H, Kumcuoglu S, Tavman S (2016) Effect of quinoa flour on gluten-free bread batter rheology and bread quality. J Cereal Sci 69:174-181

19. Machado-Alencar NM, Steel CJ, Alvim ID, Carvalho de Morais E, Andre-Bolini HM (2015) Addition of quinoa and amaranth flour in gluten-free breads: temporal profile and instrumental analysis. LWT-Food Sci Technol 62(2):1011-1018

20. Razavizadegan-Jahromi SH, Karimi M, Yazdi FT, Mortazavi SA (2014) Response surface optimization of Barbari bread-making process variables: interrelationship of texture, image and organoleptic characteristics; using image analysis for quality and shelf life prediction. J Food Process Preserv 38(4):1608-1621

21. Motta-Romero H, Santra D, Rose D, Zhang Y (2017) Dough rheological properties and texture of gluten-free pasta based on proso millet flour. J Cereal Sci 74:238-243

22. Martínez MM, Gómez M (2017) Rheological and microstructural evolution of the most common gluten-free flours and starches during bread fermentation and baking. J Food Eng 197:78-86

23. Gonzales-Barron U, Butler F (2006) A comparison of seven thresholding techniques with the k-means clustering algorithm for measurement of bread-crumb features by digital image analysis. J Food Eng 74(2):268-278

24. Gonzales-Barron U, Butler F (2008) Discrimination of crumb grain visual appearance of organic and non-organic bread loaves by image texture analysis. J Food Eng 84(3):480-488

25. Matlab software (2015) "Version R2015a". Natick. Massachusetts, The MathWorks Inc., USA

26. McNeish DM, Harring JR (2017) Clustered data with small sample sizes: comparing the performance of model-based and designbased approaches. Commun Stat Simul Comput 46(2):855-869

27. R Core Team (2018) R: a language and environment for statistical computing. R Foundation for Statistical Computing, Vienna, Austria. http://www.R-project.org/. Accessed 4 Feb 2018

28. Han HM, Cho JH, Kang HW, Koh BK (2012) Rice varieties in relation to rice bread quality. J Sci Food Agric 92(7):1462-1467

29. Sciarini LS, Ribotta PD, León AE, Pérez GT (2010) Influence of gluten-free flours and their mixtures on batter properties and bread quality. Food Bioprocess Tech 3(4):577-585

30. Giri S, Banerji A, Lele SS, Ananthanarayan L (2017) Effect of addition of enzymatically modified guar gum on glycemic index of selected Indian traditional foods (idli, chapatti). Bioact Carbohydr Dietary Fibre 11:1-8

31. Funami T, Kataoka Y, Omoto T, Goto Y, Asai I, Nishinari K (2005) Food hydrocolloids control the gelatinization and retrogradation behavior of starch. 2a. Functions of guar gums with different molecular weights on the gelatinization behavior of corn starch. Food Hydrocoll 19(1):15-24

32. Horstmann SW, Axel C, Arendt EK (2018) Water absorption as a prediction tool for the application of hydrocolloids in potato starch-based bread. Food Hydrocoll 81:129-138 
33. Sanguinetti AM, Secchi N, Del Caro A, Fadda C, Fenu PAM, Catzeddu P, Piga A (2015) Gluten-free fresh filled pasta: The effects of xanthan and guar gum on changes in quality parameters after pasteurisation and during storage. LWT-Food Sci Technol 64(2):678-684

34. Hager A-S, Wolter A, Czerny M, Bez J, Zannini E, Arendt EK, Czerny M (2012) Investigation of product quality, sensory profile and ultrastructure of breads made from a range of commercial gluten-free flours compared to their wheat counterparts. Eur Food Res Technol 235(2):333-344

35. Marti A, Marengo M, Bonomi F, Casiraghi MC, Franzetti L, Pagani MA, Iametti S (2017) Molecular features of fermented teff flour relate to its suitability for the production of enriched gluten-free bread. LWT-Food Sci Technol 78:296-302
36. de la Hera E, Rosell CM, Gómez M (2014) Effect of water content and flour particle size on gluten-free bread quality and digestibility. Food Chem 151:526-531

37. Onyango C, Mutungi C, Unbehend G, Lindhauer MG (2011) Modification of gluten-free sorghum batter and bread using maize, potato, cassava or rice starch. LWT-Food Sci Technol 44(3):681-686

38. Lee H, Coates GA (2003) Effect of thermal pasteurization on Valencia orange juice color and pigments. LWT-Food Sci Technol 36(1):153-156

39. Schober TJ, Messerschmidt M, Bean SR, Park S-H, Arendt EK (2005) Gluten-free bread from sorghum: quality differences among hybrids. Cereal Chem 82(4):394-404 